\title{
Autofluorescence imaging - a useful adjunct in imaging macular trauma
}

This article was published in the following Dove Press journal:

Clinical Ophthalmology

8 December 2010

Number of times this article has been viewed

\section{Mohammed S Mustafa \\ Vikki A McBain \\ Christopher M Scott}

Department of Ophthalmology, Aberdeen Royal Infirmary,

Aberdeen, UK
Correspondence: MS Mustafa Department of Ophthalmology, Aberdeen Royal Infirmary, Foresterhill, Aberdeen AB25 2ZN, UK Tel +44I 224552543

Fax +441224551390

Email drsohaib.mustafa@gmail.com
Abstract: Autofluorescence imaging is a rapid, noninvasive technique, with several applications becoming slowly integrated into ophthalmic clinical practice. We describe its use as a valuable tool for predicting the function of the retinal pigment epithelium following damage from blunt ocular trauma.

Keywords: autofluorescence, commotio retinae, macular detachment, eye trauma

A 25-year-old male fisherman sustained a severe blunt whiplash injury to the left eye from a recoiling rope. On examination, his best-corrected visual acuity was perception of light. Biomicroscopic examination revealed a 2-mm hyphema, traumatic mydriasis, and extensive commotio retinae with associated gross macular detachment and fine vitreous hemorrhage. After 4 months, the macular area exhibited fibrosis and scarring secondary to the macular detachment. His vision had improved to counting fingers.

Isolated traumatic macular detachment is rarely imaged due to its rarity and poor prognosis. The most common imaging techniques performed are fundus fluorescein angiography (FFA) and time-domain ocular coherence tomography (OCT; Stratus 3000, Zeiss, London, UK). However, these do not give information about the functionality of the retinal pigment epithelium (RPE). A newer imaging technique, fundus autofluorescence imaging (AF; Heidelberg retina angiograph 2, Heidelberg, Germany), is derived from lipofuscin in the RPE. ${ }^{1}$ The lipofuscin signal results in part from incomplete degradation of phagocytosed photoreceptor outer segments and therefore can provide valuable information about the metabolic activity of RPE cells and pathogenesis of retinal disorders. ${ }^{2}$ AF imaging could also allow us to offer the patient a prognostic indicator of visual outcome. AF imaging is becoming more readily available as a complementary imaging modality in ophthalmology, not only for the diagnosis of retinal disorders such as pattern dystrophy, ${ }^{3}$ but also for the management of disease progression in patients with Stargardt's disease. ${ }^{2}$

Imaging was done $\sim 3$ months postinjury (see Figure 1 ). The AF imaging provided useful information regarding the integrity of the surrounding RPE. There was widespread mottled hypo-AF which extends superiorly, and functionally indicated loss of RPE cells. At the leading edge of this was an area of hyper-AF which has been shown in cases of geographic atrophy to precede the enlargement of the hypo-AF signal. ${ }^{4}$

We recognize that with the advent of combined high-resolution spectral-domain OCT and scanning laser ophthalmoscope (SLO) systems, simultaneous AF and OCT imaging would have provided direct comparison of structure and function. 

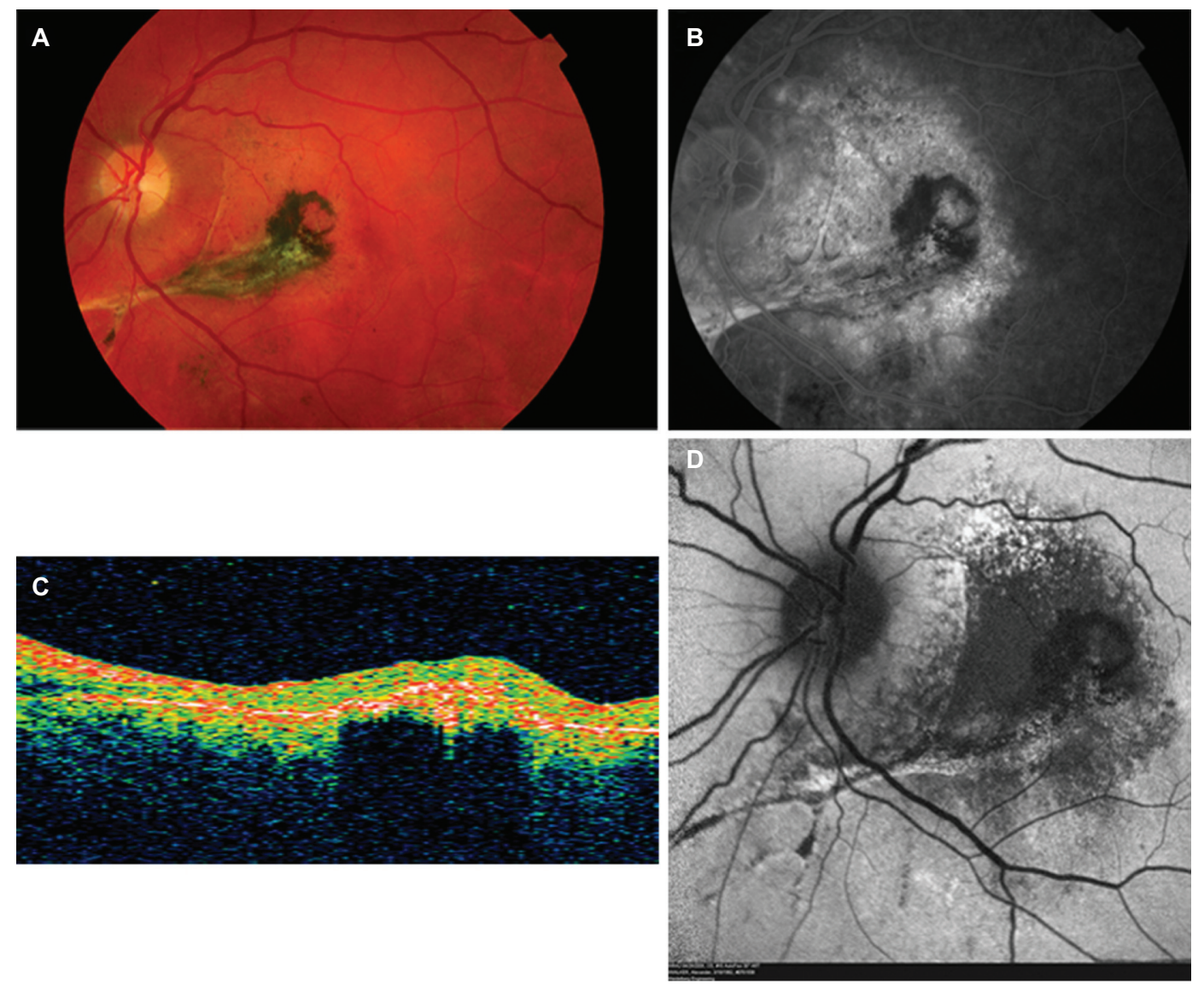

Figure I A) Fundus photo showing severe submacular fibrosis and healed choroidal rupture with its scar involving and extending beyond the posterior pole. B) FFA demonstrates blocked and hyperfluorescence in the area of submacular fibrosis. C) TD-OCT confirms the submacular fibrosis with increased reflectance at the site. D) Autofluorescence imaging clearly delineates the submacular scar and in addition reveals RPE damage extending further than anticipated, with areas of both hypo- and hyper-AF.

Fundus autofluorescence imaging is not only a rapid and noninvasive technique, but it can also provide the clinician with information on the function or health of the RPE in cases such as this. In addition, it can be used in cases where FFA is contraindicated.

\section{Disclosure}

The authors report no conflicts of interest in this work. This short report has been supported by Fighting for Sight, Aberdeen, SC No. 033004

\section{References}

1. von Rückmann A, Fitzke FW, Bird AC. Distribution of fundus autofluorescence with a scanning laser ophthalmoscope. Br J Ophthalmol. 1995;79(5):407-412.

2. Lois N, Forrester JVF. Fundus Autofluorescence. 1st ed. Philadelphia, PA: Lippincott, Williams \& Wilkins; 2009.

3. Renner AB, Tillack H, Kraus $\mathrm{H}$, et al. Morphology and functional characteristics in adult vitelliform macular dystrophy. Retina. 2004; 24(6):929-939.

4. Holz FG, Bellman C, Staudt S, Schütt F, Völcker HE. Fundus autofluorescence and development of geographic atrophy in agerelated macular degeneration. Invest Ophthalmol Vis Sci. 2001;42(5): 1051-1056.
Clinical Ophthalmology

\section{Publish your work in this journal}

Clinical Ophthalmology is an international, peer-reviewed journal covering all subspecialties within ophthalmology. Key topics include: Optometry; Visual science; Pharmacology and drug therapy in eye diseases; Basic Sciences; Primary and Secondary eye care; Patient Safety and Quality of Care Improvements. This journal is indexed on

\section{Dovepress}

PubMed Central and CAS, and is the official journal of The Society of Clinical Ophthalmology (SCO). The manuscript management system is completely online and includes a very quick and fair peer-review system, which is all easy to use. Visit http://www.dovepress.com/ testimonials.php to read real quotes from published authors. 